\title{
The State of Criminality in Tajikistan
}

\author{
Tacikistan'da Suçluluk Durumu
}

\section{Yuldoshev Rifat RAHMADJONOVICH ${ }^{1}{ }^{\oplus}$, Safarzoda Anvar ISLOM ${ }^{2}$ ๑, Mahmadzoda NERU ${ }^{3}$}

\author{
${ }^{1}$ Associate Professor, Academy of the Ministry of Internal Affairs, Faculty for leadership Training in Law \\ Enforcement and Security Agencies, Dushanbe City, Republic of Tajikistan \\ ${ }^{2}$ Associate Professor, Tajik National University, Law Faculty, Dushanbe City, Republic of Tajikistan \\ ${ }^{3}$ Postgraduate Student, Tajik National University, Law Faculty, Dushanbe City, Republic of Tajikistan
}

ORCID: Y.R.R. 0000-0002-0869-5340; S.A.I. 0000-0001-9522-9710; M.N. 0000-0002-5348-8965

\section{ABSTRACT}

The research analyzes the quantitative and qualitative components of criminality, and focuses on the 27-year period of the evolution of criminality in independent Tajikistan. Criminal policy and statistics are examined through the prism of theory, history, practice, figures and facts, contemporary achievements of the legislation and prospects for the development of a modern society. The authors propose different variations, cite and compare the points of prominent criminologists and independent experts in the context of their accuracy and timely application. Additionally, a detailed analysis of registered crimes indicates a radical revision of the domestic system's registration discipline, in particular, and criminal policy in general. The research analyzed the "pros" and "cons" of the social control of criminality as well as specified the collection, processing and thorough analysis of statistical data. The research takes timely decisions and a transition to the digitalization format of the entire criminal policy process. The context of the study is compatible with the strategic goals and objectives of reforming the internal affairs bodies of the MIA of the Republic of Tajikistan, which follows from the contents of the Police reform strategy for 2013-2020, the Police reform (development) program for 2014-2020, and other adopted regulatory legal acts and developed projects of these documents.

Keywords: Criminal policy, criminality, statistical data 


\section{Introduction}

Criminality, as a complex and socially dangerous phenomenon, contributes to the destabilization of social relations and the emerging and harmonious development of areas of activity of any society or state. In countries with high rates of crime, the state can only monitor the level of criminality and analyze the main tendencies in its growth or decrease.

The efforts of the state in the context of counteracting various manifestations of criminal acts accelerates the pace of variation of certain types of criminal acts, which have recently been carried out professionally and often in an organized manner.

The intensification of all actions to control the state of criminality, their official calculation and the division into groups and separate types is a pre-condition on the fight against criminality (it should be noted that in the text of this article, the phrases "fight against criminality", "counteraction to criminality" and "social control over criminality", which are of equal importance when designating one action, are used).

Statistics on the state of criminality in Tajikistan are distorted and have long ceased to be the basis for the formation of the criminal policy of the state, but merely serve to evaluate the work of agencies involved in the fight against criminality. Soviet and then Russian criminologists have been raising this problem for decades. The lack of state demand for reliable data on the state of criminality and their qualitative analysis has led to a crisis of criminology in Russia - it is practically not studied by lawyers, thereby losing sight of criminality as a complex social phenomenon that cannot be directly influenced by laws. The work of criminologists within departmental research institutes focuses on separate narrow issues while there is a full understanding of the limitations of existing statistics. The "stick system" still determines the behavior of police officers and other agencies, affecting the level, dynamics and structure of registered crimes and offenses.

A complete picture of the state of criminality, the effectiveness of social control measures and the activities of criminal justice authorities, as well as the development of a state policy to combat criminality are possible only with a statistical analysis of the most complete array of registered crimes.

However, the State's reliance on such distorted data has proven to not provide an accurate picture of the actual state of criminality beyond evaluating the work of law enforcement agencies. As such, the mechanisms currently in place only provide an 
artificial picture that has not changed for many years (Shklyaruk, Skugarevsky and Dmitrieva et al., 2015). This then brings into question the effectiveness of the containment of criminality in Russia. The costs of the current criminal policy and the functioning of the law enforcement and penitentiary system seem unreasonably high compared to the level of protection of the country's inhabitants that they are able to provide (Shepeleva, 2019).

Given the shared history between Russia and Tajikistan, similar shortcomings also exist in Tajikistan in terms of criminality and its containment. This research focuses on the period of post-dissolution of the USSR and developments in Tajikistan relating to criminality since then.

It should be noted that the planned police reform in Tajikistan provides for a set of organizational and managerial measures related to changing the criteria for evaluating activities, increasing the accessibility of police to citizens, as well as radically improving the system for detection, recording and registration of crimes.

The reforms of the criminal justice system are also impacted by developments in other sectors. In this regard, the government's the list of priority areas for development and science (2014) notes the issues of combating criminality, especially corruption, terrorism, extremism, drug trafficking, human trafficking, organized transnational criminality and criminality prevention. Additionally, the criminal justice system is also impacted by issues of legislative conflicts, and ensuring coordination amongst stakeholders.

The indicated context demonstrates the high level of quality in the fight against criminality, improving the image of law enforcement agencies, strengthening the stability in law-making and law-explanatory activities. Although the legislative framework towards criminal justice in Tajikistan has improved and is up to date, the lack of and challenges in implementation hampers its effectiveness.

\section{Findings and Discussion}

In 2017 , the criminality rate amounted to 249 crimes per 100,000 population in the Republic of Tajikistan, which is lower than in the Russian Federation $(1402 / 100,000)$ and the Republic of Kazakhstan $(1754 / 100,000)$, and higher than in the Republic of Uzbekistan (228/100,000).

Analysis of information on registered criminality in Tajikistan indicates an interesting trend. Graph 1 and 2 provide the rate of criminality over the 38-year period. From 
1980 to 1992 , the criminality rate increased more than twice over that of 1980 during this period (Graph 1). However, from 1993 to 2008, registered criminality was shown to decline sharply in quantitative terms (Graph 2). Data following this period, i.e. from 2009 to 2018, shows a sharp increase in the number of registered crimes (Graph 3).

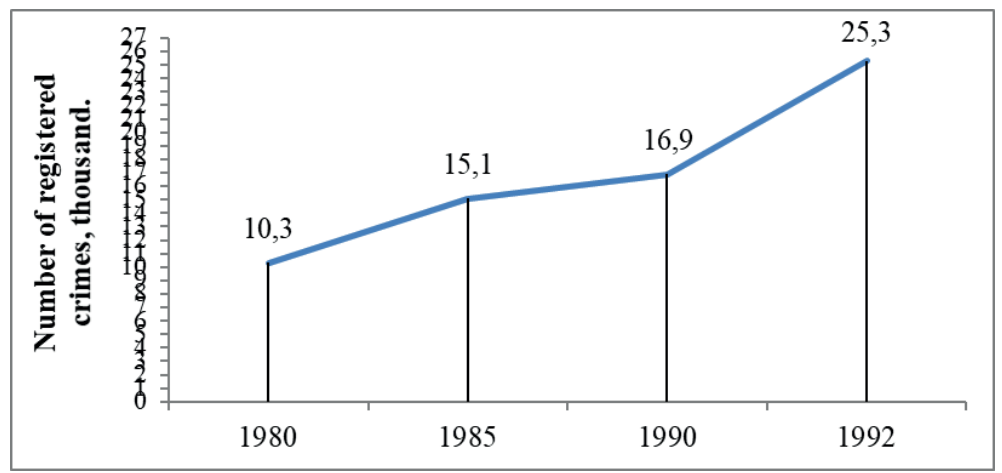

Graph 1. The growth of registered criminality in Tajikistan from 1980 to 1992

(MIA database, unpublished)

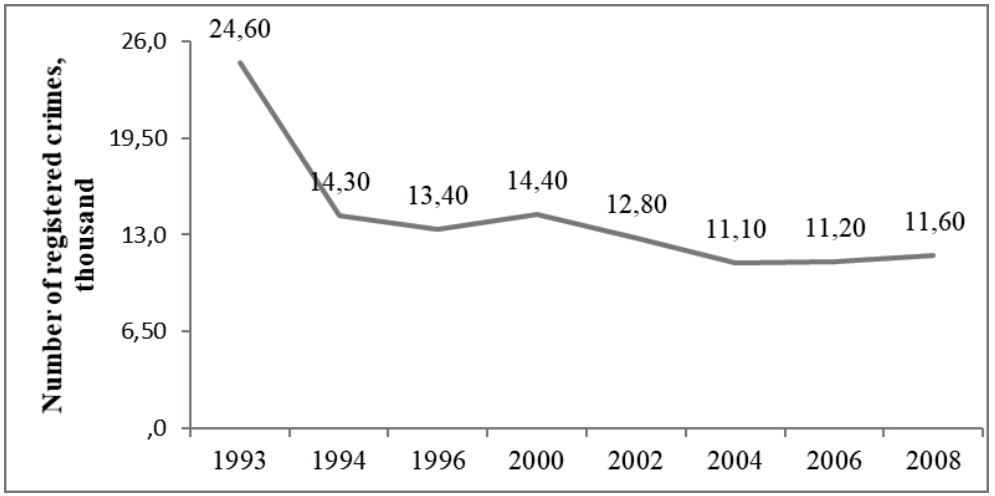

Graph 2. Decline of registered criminality in Tajikistan from 1993 to 2008

(MIA database, unpublished) 


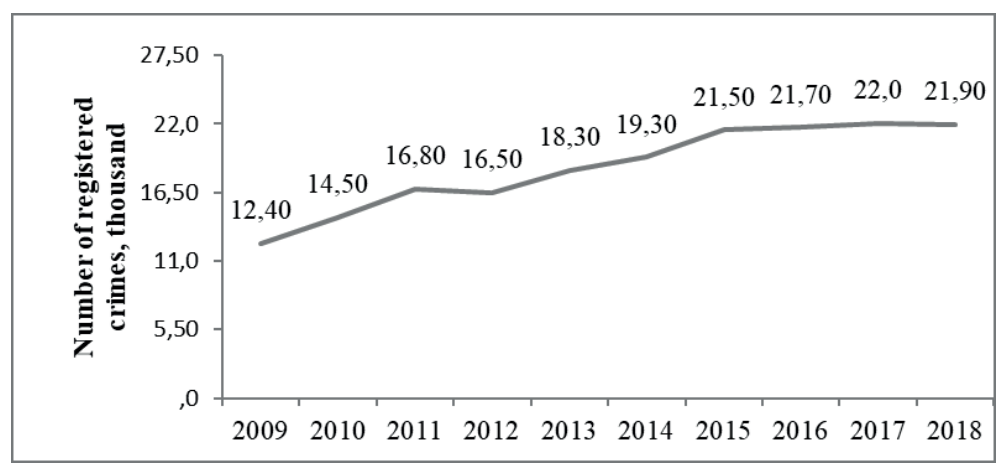

Graph 3. Registered criminality growth from 2009 to 2018 (MIA database, unpublished)

Similar trends can also be found in other CIS countries. For example, in Russia over the past 26 years there has been a trend in the growth of criminality in each subsequent decade, with a gradual decrease in the period from 2006 to 2018 (Graph 4).

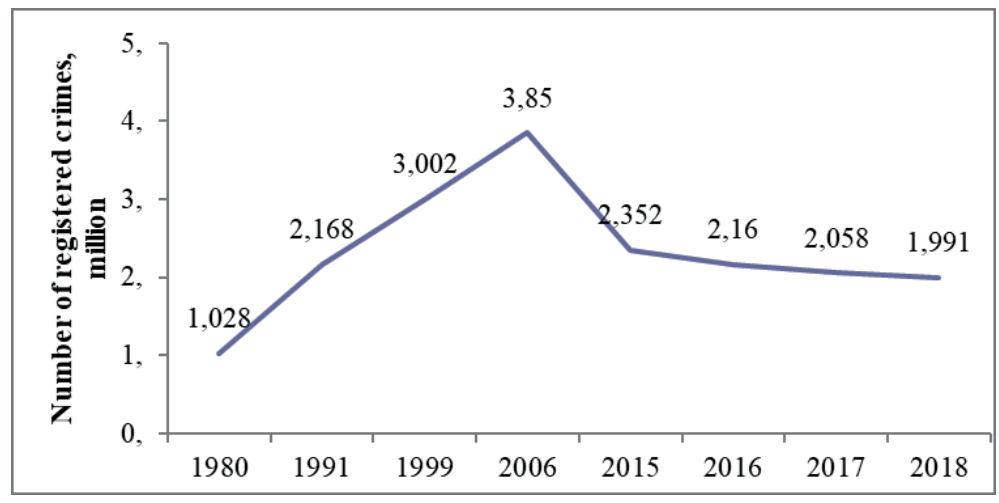

Graph 4. Criminality indicators in Russia from 1980 to 2018 (in millions)

(MIA database, unpublished)

However, Rogova \& Yuldoshev (2017) and Yuldoshev, Makhmadiev \& Akbarzoda (2018) register a note of caution on the unreliability of Russian statistics on criminality and its latency when comparing them with other countries.

Additionally, it's also important to consider the disaggregated data on criminality in Tajikistan. As such the following tables (1-4) provide data on: the number of registered 
and unsolved crimes; the number of investigated criminal cases; the number of suspended criminal cases; the number of criminal cases whose investigation terms have expired and the general indicators of crime disclosure in certain areas.

Table 1. Dynamics of registered crimes in the Republic of Tajikistan for 1980-2018

\begin{tabular}{|c|c|c|}
\hline Years & Number of registered crimes & Growth over the previous year (\%) \\
\hline 1980 & 10,380 & - \\
\hline 1985 & 15,145 & +1.45 \\
\hline 1986 & 13,880 & -0.91 \\
\hline 1987 & 12,798 & -0.92 \\
\hline 1988 & 13,755 & +1.07 \\
\hline 1989 & 16,399 & +1.19 \\
\hline 1990 & 16,887 & +1.02 \\
\hline 1991 & 18,476 & +1.09 \\
\hline 1992 & 25,296 & +1.36 \\
\hline 1993 & 24,651 & -0.97 \\
\hline 1994 & 14,278 & -0.57 \\
\hline 1995 & 14,530 & +1.01 \\
\hline 1996 & 13,388 & -0.92 \\
\hline 1997 & 13,201 & -0.98 \\
\hline 1998 & 13,161 & -0.99 \\
\hline 1999 & 14,413 & +1.09 \\
\hline 2000 & 14,455 & +1.00 \\
\hline 2001 & 14,117 & -0.97 \\
\hline 2002 & 12,754 & -0.91 \\
\hline 2003 & 11,150 & -0.87 \\
\hline 2004 & 11,037 & -0.98 \\
\hline 2005 & 12,074 & +1.09 \\
\hline 2006 & 11,223 & -0.92 \\
\hline 2007 & 12,115 & +1.07 \\
\hline 2008 & 11,658 & -0.96 \\
\hline 2009 & 12,408 & +1.06 \\
\hline 2010 & 14,548 & +1.17 \\
\hline 2011 & 16,864 & +1.15 \\
\hline 2012 & 16,593 & -0.98 \\
\hline 2013 & 18,336 & +1.10 \\
\hline 2014 & 19,352 & +1.05 \\
\hline 2015 & 21,585 & +1.11 \\
\hline 2016 & 21,756 & +1.00 \\
\hline 2017 & 22,018 & +1.01 \\
\hline 2018 & 21,957 & -0.99 \\
\hline
\end{tabular}

Source: MIA database, unpublished 
Table 2. General information on registered and unsolved crimes in the Republic of Tajikistan for 1991-2018

\begin{tabular}{|c|c|c|c|}
\hline Years & $\begin{array}{c}\text { Number of registered } \\
\text { crimes }\end{array}$ & $\begin{array}{c}\text { Number of suspended crim- } \\
\text { inal cases over p. } 1-3 \text { part } \\
1 \text { article } 230 \text { of the Code of } \\
\text { Criminal Procedure }\end{array}$ & Disclosure (\%) \\
\hline 1991 & 18,476 & 6,387 & 63.3 \\
\hline 1992 & 25,296 & 8,339 & 69.8 \\
\hline 1993 & 24,651 & 13,408 & 76.4 \\
\hline 1994 & 14,279 & 6,964 & 56.1 \\
\hline 1995 & 14,530 & 5,778 & 61.4 \\
\hline 1996 & 13,388 & 5,243 & 41.4 \\
\hline 1997 & 13,201 & 5,524 & 47.7 \\
\hline 1998 & 13,161 & 4,353 & 51.1 \\
\hline 1999 & 14,413 & 4,716 & 59.0 \\
\hline 2000 & 14,455 & 3,544 & 67.74 \\
\hline 2001 & 14,117 & 3,167 & 69.29 \\
\hline 2002 & 12,754 & 2,787 & 73.84 \\
\hline 2003 & 11,150 & 1,778 & 79.00 \\
\hline 2004 & 11,037 & 1,651 & 80.55 \\
\hline 2005 & 12,074 & 1,523 & 82.26 \\
\hline 2006 & 11,223 & 1,696 & 84.15 \\
\hline 2007 & 12,115 & 1,563 & 85.38 \\
\hline 2008 & 11,658 & 1,412 & 86.66 \\
\hline 2009 & 12,408 & 1,399 & 87.52 \\
\hline 2010 & 14,548 & 1,268 & 85.39 \\
\hline 2011 & 16,864 & 1,485 & 90.00 \\
\hline 2012 & 16,593 & 1,651 & 87.52 \\
\hline 2013 & 18,336 & 1,857 & 86.88 \\
\hline 2014 & 19,352 & 1,778 & 87.71 \\
\hline 2015 & 21,585 & 1,735 & 88.48 \\
\hline 2016 & 21,756 & 1,855 & 87.15 \\
\hline 2017 & 22,018 & 2,440 & 83.4 \\
\hline 2018 & 21,957 & 2,408 & 83.6 \\
\hline
\end{tabular}

Source: MIA database, unpublished 
Table 3. Common information of registered crimes in the Republic of Tajikistan (as of January 1 of each reporting year)

\begin{tabular}{|l|c|c|c|c|c|}
\hline Years & $\begin{array}{c}\text { Number of } \\
\text { registered } \\
\text { crimes }\end{array}$ & $\begin{array}{c}\text { Number of } \\
\text { investigated } \\
\text { criminal cases }\end{array}$ & $\begin{array}{c}\text { Number of sus- } \\
\text { pended criminal } \\
\text { cases over p. 1-3 } \\
\text { part 1 article 230 } \\
\text { of the Code of } \\
\text { Criminal Proce- } \\
\text { dure }\end{array}$ & $\begin{array}{c}\text { Terms of } \\
\text { investigations } \\
\text { expired }\end{array}$ & $\begin{array}{c}\text { Disclosure } \\
\mathbf{( \% )}\end{array}$ \\
\hline 1991 & 18,476 & 11,012 & 6,387 & - & 63.3 \\
\hline 1992 & 25,296 & 8,337 & 8,339 & - & 69.8 \\
\hline 1993 & 24,651 & 8,767 & 13,408 & - & 76.4 \\
\hline 1994 & 14,279 & 8,916 & 6,964 & - & 56.1 \\
\hline 1995 & 14,530 & 9,182 & 5,778 & - & 61.4 \\
\hline 1996 & 13,388 & 8,901 & 5,243 & - & 41.4 \\
\hline 1997 & 13,201 & 9,389 & 5,524 & 4,771 & 47.7 \\
\hline 1998 & 13,161 & 8,975 & 4,353 & 4,243 & 51.1 \\
\hline 1999 & 14,413 & 10,438 & 4,716 & 2,546 & 59.0 \\
\hline 2000 & 14,455 & 11,190 & 3,544 & 1,786 & 67.74 \\
\hline 2001 & 14,117 & 11,356 & 3,167 & 1,865 & 69.29 \\
\hline 2002 & 12,754 & 10,877 & 2,787 & 1,066 & 73.84 \\
\hline 2003 & 11,150 & 9,590 & 1,778 & 771 & 79.00 \\
\hline 2004 & 11,037 & 9,349 & 1,651 & 606 & 80.55 \\
\hline 2005 & 12,074 & 10,138 & 1,523 & 664 & 82.26 \\
\hline 2006 & 11,223 & 10,133 & 1,696 & 212 & 84.15 \\
\hline 2007 & 12,115 & 10,377 & 1,563 & 214 & 85.38 \\
\hline 2008 & 11,658 & 10,240 & 1,412 & 164 & 86.66 \\
\hline 2009 & 12,408 & 11,077 & 1,399 & 181 & 87.52 \\
\hline 2010 & 14,548 & 11,178 & 1,268 & 644 & 85.39 \\
\hline 2011 & 16,864 & 16,439 & 1,485 & 342 & 90.00 \\
\hline 2012 & 16,593 & 14,875 & 1,651 & 471 & 87.52 \\
\hline 2013 & 18,336 & 15,823 & 1,857 & 533 & 86.88 \\
\hline 2014 & 19,352 & 17,498 & 1,778 & 674 & 87.71 \\
\hline 2015 & 21,585 & 19,118 & 1,735 & 755 & 88.48 \\
\hline 2016 & 21,756 & 19,670 & 1,855 & 1,045 & 87.15 \\
\hline 2017 & 22,018 & 19,025 & 2,440 & 1,349 & 83.4 \\
\hline 2018 & 21,957 & 19,126 & 2,408 & 1,341 & 83.6 \\
\hline 5019 & & & & & \\
\hline
\end{tabular}

Source: MIA database, unpublished 
Table 4. Common information of registered crimes in the Republic of Tajikistan for 2000-2018 by administrative jurisdiction/province

\begin{tabular}{|l|c|c|c|c|c|c|c|}
\hline Years & $\begin{array}{c}\text { Number of } \\
\text { registered } \\
\text { crimes }\end{array}$ & $\begin{array}{c}\text { Dushan- } \\
\text { be city }\end{array}$ & $\begin{array}{c}\text { Centrally } \\
\text { administered } \\
\text { districts }\end{array}$ & $\begin{array}{c}\text { Sughd } \\
\text { region }\end{array}$ & $\begin{array}{c}\text { Khatlon } \\
\text { region }\end{array}$ & $\begin{array}{c}\text { BMAR } \\
\text { (Bada- } \\
\text { khshan) }\end{array}$ & $\begin{array}{c}\text { Dept. of } \\
\text { MIA }\end{array}$ \\
\hline 2000 & 14,455 & 4,490 & 1,776 & 4,035 & 2,940 & 505 & 709 \\
\hline 2001 & 14,117 & 4,275 & 1,695 & 4,145 & 2,821 & 604 & 577 \\
\hline 2002 & 12,754 & 3,507 & 1,718 & 3,963 & 2,511 & 585 & 470 \\
\hline 2003 & 11,150 & 3,149 & 1,627 & 3,089 & 2,314 & 470 & 501 \\
\hline 2004 & 11,037 & 2,964 & 1,491 & 3,183 & 2,541 & 455 & 403 \\
\hline 2005 & 12,074 & 3,205 & 1,620 & 3,759 & 2,608 & 445 & 437 \\
\hline 2006 & 11,223 & 3,146 & 1,660 & 3,289 & 2,238 & 448 & 442 \\
\hline 2007 & 12,115 & 3,696 & 1,843 & 3,277 & 2,460 & 381 & 458 \\
\hline 2008 & 11,658 & 3,445 & 1,672 & 3,154 & 2,564 & 361 & 462 \\
\hline 2009 & 12,408 & 3,572 & 1,906 & 3,276 & 2,759 & 392 & 503 \\
\hline 2010 & 14,548 & 3,660 & 2,164 & 4,378 & 3,469 & 404 & 473 \\
\hline 2011 & 16,864 & 4,595 & 2,431 & 5,178 & 3,751 & 454 & 455 \\
\hline 2012 & 16,593 & 4,674 & 2,650 & 4,450 & 3,904 & 444 & 471 \\
\hline 2013 & 18,336 & 4,709 & 3,042 & 4,908 & 4,610 & 559 & 508 \\
\hline 2014 & 19,352 & 4,643 & 3,590 & 5,181 & 4,874 & 583 & 481 \\
\hline 2015 & 21,585 & 4,898 & 3,865 & 5,982 & 5,702 & 643 & 495 \\
\hline 2016 & 21,756 & 4,736 & 4,069 & 5,921 & 5,894 & 613 & 523 \\
\hline 2017 & 22,018 & 4,655 & 4,571 & 5,712 & 6,105 & 681 & 294 \\
\hline 2018 & 21,957 & 4,587 & 4,287 & 6,083 & 6,002 & 672 & 326 \\
\hline
\end{tabular}

Source: MIA database, unpublished

In the last reporting period (2001-2016), there has been a noticed trend towards an increase in criminality by about 9-11\% (Bahridinzoda, 2016). However, it is important to note that given the variation in the recording and registering of data, these trends may have also been affected by this factor. As such, there is an urgent need to harmonize the procedures and methods of recording and registration across all related institutions and stakeholders.

The results of a special sociological study on various problems of criminality revealed a number of specific problems that were brought to the attention of the Government (Prosecutor General Office, 2019). One of the most important conditions for determining the effectiveness of criminal policy is the timely and correct registration of crimes and the detection of a real state of criminality. In this regard, the analysis showed that there are still unregistered crimes, and in 2018, prosecutors detected 945 (1,042 in 2017) unregistered crimes by other law enforcement agencies. 
The study also showed that $75.9 \%$ of respondents that participated in the survey noted a decrease of criminality in Tajikistan over the past two years and that the criminality rate in the country decreased as a whole. Additionally, the study also found that when a crime occurred, in only 87 out of $145(60 \%)$ cases were law enforcement agencies approached to take action. Furthermore, according to law enforcement agencies, 63 allegations (out of 87 ) or $72 \%$ were received and registered, and the remaining (28\%) messages and allegations of crimes were not registered.

According to the vast majority of respondents (48.4\%), the main reasons for refusing to accept and not registering the reports of crime were ambiguities in terms of jurisdiction of the case and whether the agency had the mandate to accept the reported crime. The study recommended strengthening public relations, conducting awareness and focusing on capacity development in order to address the issues within law enforcement in relation to criminality. Nazarov (2017) also notes the importance of ensuring the respect for individual freedoms and rights as a means to address the issues within the criminal justice system.

From the perspective of the victim, the most important and relevant indicator in the effectiveness of the criminal justice system is the access and time lag from reporting to investigation, and finally to judicial review and decision. In this regard, Volkov, Dmitrieva, Skugarevsky et al. (2014) note that the actual time from the commission of the crime to the decision on the case is always longer than the procedural time limits for the consideration of cases, since their calculation does not take into account the days off and preliminary investigation, and the judicial investigation and hearing of the case as well as the corresponding procedural terms can be extended.

According to estimates of authoritative experts, out of 12-15 million crimes in Russia, more than 3 million (or 20-25\%) of them are registered; of these, about $10 \%$ of crimes are detected and about five people are sentenced to various types of punishment per 100 people who have actually committed crimes, including less than $1 / 3$ to imprisonment. Latent criminality annually approaches $80 \%$ in comparison with real criminality (in European countries - about 50\%). Every year, about 7-8 million law-abiding citizens who actually suffered from latent crimes do not receive any legal assistance from the state (Luneev, 2017; Antonyan, 2015).

The situation with the criminalization of society also exists in Tajikistan, where every year (over the past 10 years) 10 to 16 thousand citizens are prosecuted (Table 5). 
Table 5. Total identified persons who committed crimes and imposed punishments and measures of a criminal-legal nature (as a percentage)

\begin{tabular}{|l|c|c|c|c|c|c|}
\hline Years & $\begin{array}{c}\text { Identified } \\
\text { persons who } \\
\text { committed } \\
\text { crimes }\end{array}$ & $\begin{array}{c}\text { Imprison- } \\
\text { ment }\end{array}$ & $\begin{array}{c}\text { Correctional } \\
\text { work }\end{array}$ & Penalty & $\begin{array}{c}\text { On } \\
\text { probation }\end{array}$ & $\begin{array}{c}\text { Other } \\
\text { measures }\end{array}$ \\
\hline 1 & 2 & 3 & 4 & 5 & 6 & 7 \\
\hline 1991 & 11,112 & 24.7 & 22.3 & 20.3 & 14.4 & 1.8 \\
\hline 1995 & 9,083 & 44.4 & 10.8 & 6.3 & 25.2 & 1.0 \\
\hline 2000 & 8,906 & 44.8 & 7.5 & 7.1 & 25.5 & 3.2 \\
\hline 2005 & 7,494 & 48.9 & 13.1 & 11.4 & 20.3 & 5.2 \\
\hline 2010 & 7,927 & 48.2 & 10.0 & 20.5 & 12.9 & 7.5 \\
\hline 2011 & 10,422 & 48.6 & 8.6 & 24.4 & 11.7 & 5.8 \\
\hline 2012 & 12,798 & 42.2 & 8.1 & 25.4 & 17.5 & 5.7 \\
\hline 2013 & 13,469 & 35.9 & 7.4 & 32.4 & 16.5 & 6.3 \\
\hline 2014 & 14,542 & 35.0 & 6.4 & 37.2 & 15.0 & 5.0 \\
\hline 2015 & 15,593 & 39.6 & 7.1 & 33.5 & 13.7 & 4.9 \\
\hline 2016 & 16,317 & 45.9 & 5.98 & 31.98 & 9.84 & 7.11 \\
\hline 2017 & 15,280 & 42.9 & 6.8 & 31.6 & 11.1 & 7.6 \\
\hline 2018 & 16,258 & 38.8 & 6.3 & 36.1 & 11.1 & 7.7 \\
\hline
\end{tabular}

Source: (MIA database, unpublished)

It seems rational to give a criminological description of persons who committed crimes, relying primarily on information obtained in the course of studying law enforcement practice, since the current statistical reporting forms do not provide a complete picture of both the crimes themselves and the individuals guilty for their commission.

At the same time, the authors suppose that the socio-demographic characteristics themselves are non-criminogenic. They are associated with the conditions of the formation of the personality, an individual's life, their interactions, socio-economic conditions and the social roles of a person. Therefore, these factors are important in studying crimes and criminality.

Furthermore, it is also important to note that the state, structure and dynamics of criminality among men and women are not the same. These differences are primarily affected by the gendered roles in society, the social and cultural values and attitudes, as well as the variations in the general socio-economic conditions across regions (Table 6). 
Table 6. Total number of identified criminals and their distribution by gender

\begin{tabular}{|l|c|c|c|}
\hline Years & $\begin{array}{c}\text { Identified persons } \\
\text { who committed } \\
\text { crimes }\end{array}$ & Men & Women \\
\hline 1991 & 11,112 & 9,982 & 1,130 \\
\hline 1995 & 9,083 & 8,147 & 943 \\
\hline 2000 & 8,906 & 7,904 & 1,002 \\
\hline 2005 & 7,494 & 6,323 & 1,171 \\
\hline 2010 & 7,927 & 6,144 & 972 \\
\hline 2011 & 10,422 & 9,111 & 1,306 \\
\hline 2012 & 12,798 & 11,169 & 1,630 \\
\hline 2013 & 13,469 & 11,692 & 1,778 \\
\hline 2014 & 14,542 & 12,666 & 1,878 \\
\hline 2015 & 15,593 & 13,719 & 1,880 \\
\hline 2016 & 16,317 & 14,581 & 1,739 \\
\hline 2017 & 15,280 & 13,572 & 1,708 \\
\hline 2018 & 16,258 & 14,618 & 1,640 \\
\hline
\end{tabular}

In terms of demographics, age is also another important factor when analyzing crime and criminality. Statistics show that among those that commit crimes, more than half (only 60.07\% in 2016) are people aged 30 years and older (Table 7).

Table 7. Total number of identified criminals and their distribution by age criteria

\begin{tabular}{|l|c|c|c|c|c|c|}
\hline \multirow{2}{*}{ Years } & \multirow{2}{*}{$\begin{array}{c}\text { Identified } \\
\text { persons who } \\
\text { committed } \\
\text { crimes }\end{array}$} & $\begin{array}{c}\mathbf{1 4 - 1 5} \\
\text { years old }\end{array}$ & $\begin{array}{c}\mathbf{1 6 - 1 7} \\
\text { years old }\end{array}$ & $\begin{array}{c}\mathbf{1 8 - 2 4} \\
\text { years old }\end{array}$ & $\begin{array}{c}\mathbf{2 5 - 2 9} \\
\text { years old }\end{array}$ & $\begin{array}{c}\text { 30 years or } \\
\text { older }\end{array}$ \\
\hline 1991 & 11,112 & 417 & 1,111 & 2,443 & 2,391 & 4,750 \\
\hline 1995 & 9,083 & 267 & 685 & 2,414 & 1,788 & 3,936 \\
\hline 2000 & 8,906 & 139 & 343 & 2,028 & 1,836 & 4,560 \\
\hline 2005 & 7,494 & 119 & 318 & 1,546 & 1,211 & 4,300 \\
\hline 2010 & 7,927 & 46 & 328 & 1,641 & 1,215 & 3,884 \\
\hline 2011 & 10,422 & 121 & 363 & 2,354 & 1,880 & 5,699 \\
\hline 2012 & 12,798 & 117 & 543 & 2,562 & 2,133 & 7,441 \\
\hline 2013 & 13,469 & 129 & 609 & 2,592 & 2,306 & 7,826 \\
\hline 2014 & 14,542 & 170 & 617 & 2,863 & 2,478 & 8,416 \\
\hline 2015 & 15,593 & 130 & 522 & 258 & 2,006 & 4,835 \\
\hline 2016 & 16,317 & 118 & 545 & 2,799 & 3,053 & 9,805 \\
\hline 2017 & 15,280 & 97 & 596 & 2,463 & 2,823 & 9,301 \\
\hline 2018 & 16,258 & 209 & 588 & 2,145 & 2,820 & 10,496 \\
\hline
\end{tabular}


The economic conditions of an individual also constitute an important factor in engaging in criminal activities. Research elsewhere has indicated that the likelihood of engaging in criminal behavior decreases with the increase in employment opportunities. This is partly explained by the fact that a predictable and secure income reduces the incentive to engage in criminal activity. Additionally, employment may also lead to positive social capital, thereby reducing the incentive to engage in socially disruptive activities such as crimes. Given this, this study also looks at the data on crimes in association with employment characteristics to better understand the state of crimes in Tajikistan (Table 8).

Table 8. Total number of identified criminals and their distribution at the time of the crime based on their employment

\begin{tabular}{|c|c|c|c|c|}
\hline \multirow[t]{2}{*}{ Years } & \multirow{2}{*}{$\begin{array}{c}\text { Identified persons } \\
\text { who committed } \\
\text { crimes }\end{array}$} & \multicolumn{3}{|c|}{$\begin{array}{l}\text { Based on their employment at the time of crime } \\
\text { commission }\end{array}$} \\
\hline & & Worker & Employee & Members of peasant farms \\
\hline 1991 & 11,112 & 5,330 & 519 & 1,776 \\
\hline 1995 & 9,083 & 3,034 & 748 & 732 \\
\hline 2000 & 8,906 & 798 & 675 & 865 \\
\hline 2005 & 7,494 & 358 & 114 & 628 \\
\hline 2010 & 7,927 & 307 & 193 & 43 \\
\hline 2011 & 10,422 & 763 & 1,113 & 29 \\
\hline 2012 & 12,798 & 499 & 452 & 21 \\
\hline 2013 & 13,469 & 807 & 1,198 & 18 \\
\hline 2014 & 14,542 & 782 & 1,099 & 4 \\
\hline 2015 & 15,593 & 346 & 538 & 2 \\
\hline 2016 & 16,317 & 527 & 852 & 2 \\
\hline 2017 & 15,280 & 545 & 818 & 1 \\
\hline 2018 & 16,258 & 843 & 1,231 & 10 \\
\hline
\end{tabular}

Education constitutes another essential element in characterizing an individual's propensity to engage in criminal activities. A high level of education is regarded as an anti-criminogenic factor, and after serving the sentence facilitates social adaptation of prisoners. The level of education also plays a significant role in the likelihood of participation in criminal activity: the higher the level of education, the lower the likelihood that a person will engage in criminal activity. Another factor is the presence of a family and dependents - facts that usually contribute to a decrease in the level of participation in criminal activity (Volkov et al., 2014). 
The study shows the majority of illegal acts are committed mainly by persons with secondary and specialized secondary education (89.59\% in 2016). The proportion of people with higher and specialized secondary education does not exceed $10.40 \%$ (Table 9).

Table 9. Total number of identified criminals and their distribution by educational qualification

\begin{tabular}{|l|c|c|c|}
\hline \multirow{2}{*}{ Years } & \multirow{2}{*}{$\begin{array}{c}\text { Identified persons who } \\
\text { committed crimes }\end{array}$} & $\begin{array}{c}\text { By education at the time of the crimes commission } \\
\text { Special education }\end{array}$ & $\begin{array}{c}\text { Secondary education } \\
\text { (complete and incomplete) }\end{array}$ \\
\hline 1991 & 11,112 & 2,267 & 8,842 \\
\hline 1995 & 9,083 & 1,600 & 7,484 \\
\hline 2000 & 8,906 & 1,645 & 6,266 \\
\hline 2005 & 7,494 & 957 & 5,961 \\
\hline 2010 & 7,927 & 804 & 5,961 \\
\hline 2011 & 10,422 & 2,466 & 7,181 \\
\hline 2012 & 12,798 & 2,252 & 9,700 \\
\hline 2013 & 13,469 & 1,931 & 10,663 \\
\hline 2014 & 14,542 & 2,298 & 11,494 \\
\hline 2015 & 15,593 & 1,411 & 14,188 \\
\hline 2016 & 16,317 & 1,698 & 14,622 \\
\hline 2017 & 15,280 & 1,507 & 13,773 \\
\hline 2018 & 16,258 & 1,993 & 14,265 \\
\hline
\end{tabular}

In order to fully determine the whole picture of criminality in Tajikistan for the analyzed period, we consider it appropriate to define its "indicators". We take as a basis for determining criminality indicators the methodology proposed by Professor Ya.I. Gilinsky (2013). According to him, the main indicators that are relevant in examining criminality are:

1. Criminality volume - the absolute number of crimes registered in a certain territory for a certain period of time. For example, the criminality volume in Russia in 2011 amounted to 2,404,807 registered crimes.

2. Criminality rate - the number of crimes registered in a certain territory for a certain period of time, based on any number of residents of the same territory (usually per 100,000 people, although it is possible to count both 100,000 or 1,000 people). Often, the criminality rate is calculated per 100,000 residents who have reached the age of criminal liability. The criminality rate per 100,000 people is expressed by a coefficient that is calculated by the formula: 


$$
K=\frac{n+105}{N}, \text { where }
$$

$\mathrm{K}$ - criminality coefficient,

$\mathrm{n}$ - number of registered crimes in a certain territory for a certain time,

$\mathrm{N}$ - population (or population from the age of 14) in the same territory.

For example, we know that criminality volume in Russia in 2011 amounted to 2,404,807. The rate calculated by the above method is 1,694 . The criminality coefficient (as an indicator of its rate) allows you to compare the state of criminality in different countries and regions.

3. Criminality structure - an internal composition of criminality by type of crime (in 2011 in Russia the share of thefts amounted to $43.2 \%$ of all crimes, brigandages and robberies $-6.1 \%$, felonies against persons $-2.4 \%$, crimes of an economic nature -8.4 $\%$, crimes related to drug trafficking $-8.9 \%$, other crimes $-30.9 \%$ ), or by the sociodemographic composition of the persons committing the crimes (in 2011 in Russia female criminality was $15.3 \%$, male criminality $-84.7 \%$; juvenile criminality $-6.3 \%$, adult criminality $-93.7 \%$ ), or by any other grounds.

The share of each structural element of a crime is calculated as a percentage and is usually called the specific gravity (for instance, in our examples the specific gravity of thefts was $43.2 \%$, the specific gravity of female crime was $15.3 \%$ ).

4. Criminality dynamics - change of the above indicators (volume, rate, structure) over time. For example, the dynamics of criminality rate (per 100,000 people) in Russia from 1999 to 2011: 1999 - 2051.4; 2000-2028.3; 2001-2045.6; 2002 - 1760.5; 20031926.2; 2004 - 2007.2; 2005 - 2477.6; 2006 - 2700.7; 2007 - 2519.0; 2008 - 2260.0; 2009 - 2110.0: 2010 - 1852.0; 2011 - 1694.036.

5. Other indicators. In addition to the four main indicators mentioned above, studies in criminology also use numerous other quantitative measures to determine the characteristics of criminality (Zabryansky, 2010; Kogan, 1977; Inshakov, 1997; Maximov, 1995). These include:

- the criminal record index (the number of persons convicted to criminal punishments by sentences that have entered into legal force, in a certain territory for a certain period of time in calculation per 100,000 inhabitants); 
- criminality latency index (ratio of unregistered crime volume to its registered part);

- the coefficient of criminal activity (ratio of a certain socio-demographic group of population among the persons who committed crimes to the share of the same group in the population);

- crime disclosure rate (ratio of solved crimes to registered ones);

- victimization level (ratio of the share of a particular socio-demographic group of the population among victims of crimes to the share of this group in the population) and other, as well as integrative indicators that take into account the number of crimes, their severity and other characteristics.

6. Another concept that is necessary to understand crime and criminality is the State - that is, the generalized characteristics, including the volume, rate, structure, dynamics, latency, damage caused, etc., in a certain territory at a certain time and place. The State, as a unit of analysis, is also important given the fact that the general socioeconomic conditions vary across countries (Gilinsky, 2013).

Based on the framework outlined above, the table below presents the criminality rate of Tajikistan (Table 10).

Table 10. Total of the population, registered crimes, identified individuals and criminality rate

\begin{tabular}{|l|c|c|c|c|}
\hline Years & $\begin{array}{c}\text { Number of } \\
\text { population } \\
\text { (million) }\end{array}$ & $\begin{array}{c}\text { Registered } \\
\text { crimes }\end{array}$ & $\begin{array}{c}\text { Identified } \\
\text { individuals }\end{array}$ & $\begin{array}{c}\text { Rate } \\
\text { (per 100 thousand } \\
\text { people) }\end{array}$ \\
\hline 1991 & $5,505.6$ & 18,476 & 11,112 & 352 \\
\hline 1992 & $5,567.2$ & 25,296 & 8,606 & 477 \\
\hline 1993 & $5,579.7$ & 24,651 & 8,534 & 463 \\
\hline 1994 & $5,533.8$ & 14,279 & 9,290 & 266 \\
\hline 1995 & $5,701.4$ & 14,530 & 9,083 & 267 \\
\hline 1996 & $5,769.1$ & 13,388 & 8,297 & 243 \\
\hline 1997 & $5,875.8$ & 13,201 & 8,413 & 235 \\
\hline 1998 & $6,001.3$ & 13,161 & 7,827 & 230 \\
\hline 1999 & $6,128.5$ & 14,413 & 8,484 & 246 \\
\hline 2000 & $6,264.6$ & 14,455 & 8,906 & 242 \\
\hline 2001 & $6,371.2$ & 14,117 & 9,382 & 232 \\
\hline 2002 & $6,487.1$ & 12,754 & 8,691 & 206 \\
\hline 2003 & $6,598.8$ & 11,150 & 7,820 & 177 \\
\hline 2004 & $6,718.9$ & 11,037 & 8,395 & 172 \\
\hline 2005 & $6,842.2$ & 12,074 & 7,494 & 185 \\
\hline
\end{tabular}




\begin{tabular}{|l|l|l|l|l|}
\hline 2006 & $6,965.5$ & 11,223 & 8,327 & 169 \\
\hline 2007 & $7,096.9$ & 12,115 & 8,939 & 179 \\
\hline 2008 & $7,250.8$ & 11,658 & 8,363 & 168 \\
\hline 2009 & $7,417.4$ & 12,408 & 8,859 & 175 \\
\hline 2010 & $7,621.2$ & 14,548 & 7,927 & 200 \\
\hline 2011 & $7,807.2$ & 16,864 & 10,422 & 226 \\
\hline 2012 & $7,987.4$ & 16,593 & 12,798 & 218 \\
\hline 2013 & $8,161.1$ & 18,336 & 13,469 & 235 \\
\hline 2014 & $8,352.0$ & 19,352 & 14,542 & 243 \\
\hline 2015 & $8,551.2$ & 21,585 & 15,593 & 265 \\
\hline 2016 & $8,742.8$ & 21,756 & 16,317 & 261 \\
\hline 2017 & $8,931.2$ & 22,018 & 15,280 & 258 \\
\hline 2018 & $9,126.6$ & 21,957 & 16,258 & 252 \\
\hline
\end{tabular}

\section{Detailed Analysis of the Problem}

As part of a detailed comparison, we present the last two reporting periods (TAJSTAT, 2019; TAJSTAT, 2020), i.e. the indicators of 2018-2019. According to the official data of the Ministry of Internal Affairs of the Republic of Tajikistan, in 2018 the country registered 21,957 crimes, of which 18,199 were registered by the Ministry of Internal Affairs and the Prosecutor General's Office, which in total accounts for $82.9 \%$ of the total number of registered crimes. Other law enforcement agencies registered 3,758 crimes or $17.1 \%$ of the total number of crimes.

In 2018 , the country observed an overall decrease in the number of registered crimes by $0.3 \%$. In terms of various regions, this included a reduction in registered crimes by $1.3 \%$ in BMAR (Badakhshan Mountainous Autonomous Region), 1.6\% in Khatlon region, $1.5 \%$ in Dushanbe City, and 6.2\% in CAD (centrally administered districts), whereas there was an increase of registered crimes by $6.5 \%$ in the Sughd region.

In 2019, the country registered 21,966 crimes, of which 18,202 crimes were registered by the Ministry of Internal Affairs and the Prosecutor General's Office, which in total accounts for $82.8 \%$ of the total number of registered crimes. Other law enforcement agencies registered 3,794 crimes or $17.2 \%$ of the total number of crimes.

In 2019 , there was an increase in the number of registered crimes by $0.2 \%$ in the republic, including the Sughd region - by $4.8 \%$ and CAD - by $2.5 \%$, and a decrease in BMAR - by $0.9 \%$, Khatlon region - by $5.7 \%$ and in the city of Dushanbe - by $0.1 \%$. 
If you detail the statistical data, then in 2018, 5,158 felonies were registered, which is $0.3 \%$ less than the figures for 2017. In 2019, 4,864 felonies were registered, which is $5.7 \%$ less than the same indicators in 2018 .

In 2018, the registration of cases of intentional infliction of serious harm to health increased by $12.9 \%$, robberies - by $7.5 \%$, fraud - by $18.1 \%$, kidnapping - from 1 to 6 cases and human trafficking - from 22 to 32 cases.

In 2019, there was an increase in the incidence of murders and attempted murders by $12.8 \%$, rape and attempted rape - by $9.5 \%$, theft - by $5.3 \%$, hooliganism - by $5.7 \%$ and violation of traffic rules - by $1.8 \%$.

Compared to 2018, there has been a decrease in the registration of cases of intentional infliction of serious harm to health by $15.4 \%$, robbery - by $15.8 \%$, brigandages - by $21.6 \%$, fraud - by $11.0 \%$, crimes related to drugs - by $24.2 \%$, bribery - by $14.2 \%$, kidnapping from 6 to 5 cases and human trafficking - from 32 to 14 cases.

In 2018-2019, the number of economic crimes increased by $0.7 \%$ compared to 2017 and 2018. If in 2018 there were 3,547 crimes of this group registered, then in 2019 there were 3,572 crimes (Division of Internal Affairs revealed 1,221 crimes and initiated 1,119 criminal proceedings), which is $0.7 \%$ more crimes. This group primarily includes: bribery, embezzlement on a large and especially large scale, theft and other types of crimes.

In 2018, the number of cases of traffic violations that resulted in serious bodily harm and death of victims amounted to 499 cases, which increased by $1.4 \%$ compared to the same period in 2017. In 2019, these crimes began to decline and all in all 489 crimes were registered, which is $2.0 \%$ less.

The total crime disclosure rate in 2018 was $83.6 \%$ compared to $83.4 \%$ in 2017 . In 2019 , this indicator improved slightly and amounted to $85.8 \%$.

Increase in crime detection in Tajikistan indicates, first of all, the imperfection of the system of registration and recording of crimes, which nullifies all the concepts, strategies and programs being developed in the field of criminal-legal and criminal policy.

According to the results of studies (Gavrilov, 2008; Luneev, 2005; Alekseev, Ovchinsky $\&$ Pobegailo, 2006), the crime rate over the past decade, taking into account its latency, amounted to not 3-3.5 million crimes a year, but 4-5 times higher, which additionally emphasizes the need to increase material, financial, and technical means for this area. 
Their savings and even reduction, as evidenced by the Decree of the President of the Russian Federation from February 19, 2010 №208 “On some measures to reform the Ministry of Internal Affairs of the Russian Federation" (Collection of legislation of the Russian Federation, 2010), worsen the quality of pre-trial criminal proceedings, which, in its turn, entails the need to repeat the investigative and other procedural actions, and each such case involves additional costs of financial resources.

The results obtained in the course of O.A. Malyshev's monographic study are confirmed by other studies. So, Professor B.Ya. Gavrilov, having analyzed information on the number of registered crimes in the period from 1976 to 2008, came to the conclusion that the practice of the activities of the internal affairs bodies over the past decades, with rare exceptions, indicates an increase in the number of registered crimes by $10-$ $30 \%$ in the first year after the appointment of the head of the internal affairs body (the city, district division of the internal affairs including the Ministry of the Internal Affairs). However, as early as the next year, the level of registered crime was stabilized, and in the third year, a $5-10 \%$ reduction was seen in the number of registered crimes on the basis of which the heads of law enforcement agencies reported on their "successful" work to combat crime. This is shown quite clearly in the example of taking up positions in 1989-2004 by ministers of the internal affairs (Gavrilov, 2008).

In order to ensure the objectivity of criminal statistics back in the 1970s scientists justified an expediency of assigning the function of recording allegations of crimes to government agencies, autonomous from law enforcement agencies (Kudryavtsev, 1971; Ostroumov \& Panchenko, 1967). In this regard, V.M. Kogan's proposal to create a unified body that would perform the function of detecting crimes is of practical interest. Moreover, the effectiveness of the mentioned body would be determined by the number of detected crimes (Kogan, 1983).

Over the course of three decades a proposal by scientists and law enforcement officials appeared to create an interdepartmental center for criminal statistics (Kozhevnikov, 1998). The possibility of assigning this center to the jurisdiction of the Ministry of justice of the Russian Federation in accordance with the provisions of the Concept of judicial reform in the Russian Federation has raised objections from separate scholars (Saviuk, 2000).

The Prosecutor General's Office of the Russian Federation took a different position compared to the above. It justified the need to transfer powers from the internal affairs 
bodies to create a database of the state of criminality. This proposal of the Prosecutor General of the Russian Federation was implemented in 2003-2004 (in the form of an experiment). However, it did not solve the problem under consideration, and also required significant financial costs (Toropin, 2013).

We believe that a similar situation should be expected in connection with the transfer to the Prosecutor General of the Russian Federation, again at its suggestion, of authority to maintain the state unified statistical records of allegations and reports of crimes, the state of criminality, disclosure of crimes, the state and results of investigative work and prosecutorial supervision, and also the establishment of unified procedure for the formation and submission of reports to the prosecution authorities (Federal Law "On the Prosecutor's Office of the Russian Federation", 2011).

The authors from the Institute of law enforcement at the European University of St. Petersburg in this context indicate the need to create an independent agency for the collection and analysis of criminal statistics, which they proposed in the Concept of organizational and management reform of law enforcement agencies in 2013.

The reason that colleagues from the Institute for law enforcement at the European University of St. Petersburg emphasize their conclusions is the fact that the law enforcement agencies in Russia were solely responsible for collecting criminal statistics, which created a systemic conflict of functions, i.e.: law enforcement officers simultaneously collect information about crime, and fight with it (crime). Additionally, the authors assert themselves in their arguments that at present a number of indicators related to the investigation of crimes and the consideration of criminal cases serve to evaluate the work of police, investigators and prosecutors. In addition, the work of law enforcement agencies is largely limited only by the criminality that they take into account. Therefore, the operation for recording crimes is, in essence, the determination of the volume of their work and the level of its complexity. The combination of the function of recording crimes and the fight against it in one organization will always give rise to incentives to regulate the volume of work of the department and its complexity "at the entrance", i.e. through the recording filter (Shklyaruk et al., 2015).

Many CIS member states suffer similar problems when combating criminality. The embedded nature of the "stick system", "work for indicators" and "upholding departmental interests" instead of actually combating crimes in all its manifestations, 
regardless of forms and specific types is found across the CIS region. As such, fundamental changes at both the institutional level and the culture at law enforcement agencies are necessary in order to improve the functions of the criminal justice system across the region. As an example, we cite an excerpt from a study of independent experts who negatively assess the current system of Russia.

Analyzing the problems of recording and registration discipline, O.A. Malysheva concludes that the implementation of legal, administrative-legal and organizationallegal measures could not solve the problem of ensuring the legality of the reception and registration of allegations and messages and other information about incidents and thereby observing the rights and legitimate interests of participants in criminal proceedings who suffered from crimes, including the right to access to justice within a reasonable time and compensation for harm caused by a crime (Malysheva, 2013; Malysheva, 2019).22:42

We can illustrate the practice of registering crimes in foreign countries. For example, in the United States about 12-13 million crimes are registered annually; in Germany - 6.5 million. If in Russia the criminality coefficient in 2011-2012 per 100 thousand population was 1.7 thousand crimes, then in the USA - 5.5 thousand crimes, Germany - 8 thousand crimes, Sweden - 13.5 thousand crimes (Vedernikova, 2010).

Analyzing the various problems of criminal policy and the fight against criminality, Professor V.V. Luneev wonders: which scientific institutions (think tanks) systematically and daily track (monitor) criminality in our country, study its social, economic, demographic and spiritual basis, obtain real data on criminality and its causes, necessary objective information, scientifically digest it, predict possible trends and give reasonable criminal legal advice to the authorities. And he claims, there are none.

For the systematic development of criminal policy and effective functioning of criminal legislation it is necessary to create a criminal-legal, criminological and prognostic research center, providing it with continuous and systematic criminological and criminal-legal information, as well as an opportunity to collect the necessary information by methods of sociological surveys and studies. Such a center could conduct objective studies of real criminological and criminal-legal trends and patterns, study the effectiveness of practical activities of the criminal justice system and timely predict possible preventive measures (Luneev, 2016). Such a body can then be utilized to ensure evidence based policy making by the government, thereby improving the impact 
of the intervention measures, as well as providing data to evaluate their success and effectiveness.

In this regard, it can be noted that Tajikistan also took into account the trends in the development of criminal policy: the State Program to combat criminality in the Republic of Tajikistan for 2008-2015, approved by the Government of the Republic of Tajikistan, №543 from November 2, 2007, on the basis of the Information department of the Ministry of internal affairs of the Republic of Tajikistan planned the creation of the Unified republican center for the registration of crimes (paragraph 1.7). And such a center was created. In accordance with the Decree of the Government of the Republic of Tajikistan dated March 31, 2011, in the structure of the Ministry of Internal Affairs of the Republic of Tajikistan functions as the Main information and analytical center (MIAC). The specified Center still could not solve the actual task of obtaining an objective picture of the criminological situation in the country.

In 2009, as outlined in paragraph 1.5 of the State Program to combat criminality in the Republic of Tajikistan for 2008-2015, it was planned to create a Research institute for the suppression of criminality. As outlined in paragraph 1.6 of the cited document on the basis of the scientific part of the Academy of the Ministry of Internal Affairs of the Republic of Tajikistan it was planned to conduct an "Organization and conducting monitoring studies on the state of criminality".

As evidenced by the current state of the fight against criminality, many positive aspects of the State Program to combat criminality in the Republic of Tajikistan for 2008-2015 were not implemented; they just remained on paper. It should be noted that the conceptual directions laid down in this document, were dictated and developed not to strengthen "paperwork", but in the framework of maintaining and concretising the nationwide policy to combat criminality in its various forms and manifestations. Both before and after the adoption and introduction of the cited document, for many objective and subjective reasons and circumstances (mainly at the local level/divisions), the basic provisions were not realized, which led to bad consequences.

At the same time, the Police reform strategy adopted in 2013 and on this basis in 2014 the Police reform (development) program and the Plan for its implementation contain specific measures aimed at creating a unified state system for the reception, registration, recording, consideration of allegations and reports on crimes and incidents, the detection and disclosure of offenses, the implementation of the procedure for receiving, registering 
allegations and reports of crimes and incidents in real time (online mode), receiving information about the progress and their outcome through the electronic portal of the Ministry of Internal Affairs, as well as the regulation of cross-sectoral integration of law enforcement and other government agencies on the issues of reception, registration, recording, consideration of allegations and reports of crimes and accidents, their detection and disclosure.

So, in accordance with the Action plan for the implementation of the Police reform (development) program for 2017-2020, a draft the Law of the Republic of Tajikistan "On unified state system for registering and recording crimes" and the Decree of the Government of the Republic of Tajikistan "On a Concept for the development of informatization and unified information and communication system of internal affairs bodies for 2014-2020" and "Instructions on unified information system and the procedure for the unified recording of citizens' addresses about crimes" is planned.

Additionally, the Prosecutor General's Office has developed a draft of the Law of the Republic of Tajikistan "On the basics of crime prevention” (Yuldoshev et al., 2018), which was passed in 2015-2016 with joint approvals in various ministries and departments of the country. According to the developers, this law was intended to define the legal, economic, social and organizational foundations of crime prevention activities, crime prevention actors and their powers in crime prevention. To date, nothing is known to us about the fate of this bill.

We assume that this bill was developed in the framework of the implementation of paragraph 51 of part 18 of the Concept for the prospective development of legislation of the Republic of Tajikistan, which indicated that for further full and systematic legal regulation of issues in the field of public order protection it is necessary to develop and adopt the Law of the Republic of Tajikistan "On the basics of crime prevention". In the framework of the implementation of many documents aimed at combating criminality and strengthening counteraction in this field, an important factor is the optimization of the functioning of law enforcement agencies. Among such law enforcement agencies are the relevant structural units of the internal affairs bodies. We should be reminded that in accordance with paragraph 1.11 of the Action plan for the implementation of the Police reform (development) program for 2014-2020, the creation of a special portal of the Ministry of Internal Affairs of the Republic of 
Tajikistan to receive and register allegations and reports of crimes (Collection of regulatory legal acts on police reform, 2015) is planned.

Now, the state of recording and registration discipline in the Ministry of Internal Affairs of the Republic of Tajikistan is controlled on the basis of the Order for maintaining unified records, registering crimes and persons who committed them, as well as the Instruction "On unified order for accepting, registering, recording and resolving allegations, messages and other information on crimes and incidents", which is an integral part of the Joint directive "On the unified registration of crimes", which establishes a unified order for receiving, registering and recording allegations, messages and other information on crimes and incidents, for which verification and control of permission and decisionmaking by all law enforcement agencies of Tajikistan, who conduct an inquest, preliminary investigation, as well as judicial proceedings is carried out (Rahimzoda, 2014).

Thus, the activities of legal statistics and special recording bodies are important in the framework of legal reforms in the republic.

At the present time, the process of accepting and registering allegations and reports of crimes is carried out manually. There is no possibility of fully registering, docking and controlling data on received and registered allegations and reports of crimes and criminal cases, and citizens are not able to receive information about the state of their allegation at any time, or at what stage of the investigation the criminal case is, if it has been initiated on its allegation or message or not.

For decades, with the building of communism, the activities of law enforcement agencies, primarily the police, have been evaluated on the basis of the government's demand to achieve an ideologically prestigious status, inevitably decreasing criminality rate and demonstration of steady support of the Leninist principle of the inevitability of liability, an analogue of which is a one hundred percent disclosure of crimes. But since these results were unachievable, despite the appearance of "putting things in order", deception technology continues to be used.

In relation to the problems discussed in this study, this technology primarily serves the "art" of registration, which has generated a large amount of criminal latency. These factors give rise to a seemingly paradoxical situation: the more favorable the registration of crimes, the higher the intensity of victimization of citizens, which, if unaccounted for, sort of does not exist for the authorities. And if we take into account that the main criterion for evaluating the work of the police as the percentage of disclosure, and if 
the financial, resource, staff status of the police does not depend on the real state of crime (i.e. security level and victimization of the population), which cannot be assessed without assessing latency, then the police in order to survive in these conditions acts like any system: it begins to regulate the "entrance" by all legal and illegal means, i.e. distort and "calibrate" the real picture of crime.

As a result, citizens are limited in their constitutional rights with regards to access to justice. Indeed, the lack of full-fledged control mechanisms (including public control) creates opportunities to hide crimes from being recorded, which, in turn, increases the corruption impact on law enforcement agencies, negatively affects the effectiveness and the good faith of police officers in fulfilling their duties and entails such socially dangerous consequences as a substantial violation of the rights and legitimate interests of citizens or the interests of society or the state protected by law.

In this regard, it seems that indicators such as a decrease in the level of victimization, a decrease in the fear of becoming a victim of a crime, and an improvement in the opinion of citizens about the work of police could serve as a more or less real tool, a "barometer" of citizens' security.

Therefore, the improvement of relations between the police and citizens is the central link, a categorical imperative in building trusting and consolidating relations between the authorities and the population at a modern historical stage.

\section{Conclusion}

It should be noted that the built-in system for evaluating the activities of police must meet the most important criterion - it must fully motivate the actions of police and build relations between the police and citizens in such a way that these relationships do not serve as a destructive "barrier" that impedes citizens' access to justice.

As historical experience shows, this "barrier" cannot be eliminated by any administrative, disciplinary or other external measures.

Therefore, the Police reform strategy establishes that areas for improving criminality analysis should be accompanied by monitoring of criminal latency, i.e. a system of measures for a long-term forensic examination of persons, families, households and settlements on the issues of criminal acts against them (Yuldoshev et al., 2018).

Therefore, one of the main directions of optimizing the activities of law enforcement agencies at the level of criminality control policy, a step that anticipates a more radical 
solution to the problem, is currently to consider the work to neutralize the administrative and psychological press, which negatively affects the activities of police in criminality recording. It seems, as indicated in the Strategy, that it would be more reasonable to remove the increased responsibility from police for the number of registered and disclosed crimes. However, it is important to blame it on the completeness of the detection and registration of crimes and persons who committed crimes.

In accordance with the Strategy a set of organizational and managerial measures related to changing the criteria for evaluating activities, increasing the accessibility of police to citizens, as well as radically improving the system for detecting, registration and recording crimes will be implemented. It is also planned to transfer the state system for detecting, registering and recording crimes to work with modern information technologies, and to record all information about criminal manifestations (from initial messages to criminal procedure documents) on electronic media and accumulate them in automated information processing systems. Rather, this innovation will give a corresponding impetus to the work of law enforcement agencies.

The above system will contribute to the completeness of registration and recording of crimes and the adoption of timely measures to investigate them. On the other hand, the timely and complete registration of allegations and reports of crimes and offenses will facilitate a prompt response to them and ensure objective decision-making, which is of great importance for ensuring security and a stable situation in Tajikistan, as well as creating a civil society.

The MIA of the Republic of Tajikistan plans to create an electronic system for registering crimes, which will contribute to: further strengthening the effectiveness of the process of registering complaints and allegations of crimes; providing automated interaction of the system with the criminal statistics processing system of the MIA of the Republic of Tajikistan; providing guarantees and respect for human rights and legitimate interests of citizens; as well as increasing their confidence in law enforcement bodies. The Electronic system for registering crimes should provide citizens a simplified procedure for filing lawsuits and allegations of crimes, as well as the ability to control the process of receiving and registering complaints, and the decision-making process.

This project is the first step to ensure the constitutional rights of citizens to access justice, ensure their rights and legitimate interests or the interests of society or the state protected by law. Within the framework of the project a system for the reception, 
registration, recording, inclusion of an electronic format, and the consideration of allegations, messages, complaints and other information about crimes and incidents - "Electronic registration of allegations and reports of crimes and incidents" will be developed and implemented.

This project is aimed at ensuring a unified procedure for the reception, recording, inclusion of an electronic format, and the consideration of allegations, messages, complaints and other information about crimes and incidents. The electronic registration and recording of allegations and reports of crimes and incidents minimizes the hiding from registration of allegations and reports of crimes, that is, artificial latency on the part of police officers. On the other hand, the project will provide an opportunity to submit messages and applications from citizens while minimizing the efforts required for this, i.e. reduce natural latency. At the same time, the possibility of non-procedural contact of officials with applicants and offenders will be significantly reduced, which is one of the conditions for preventing corruption offenses by law enforcement officials.

Within the framework of the project a web portal that provides support for electronic filing of allegations and an ability to control citizens over the results of the examination of allegations and the progress of investigation, as well as modernized software for recording criminal statistics to ensure their integration within the unified database of the Integrated Databank (IDB) of the MIA of the Republic of Tajikistan will be developed. The portal will have a software connection and technology will be able to be used to interact with workplaces of employees of duty units of the Division of the MIA of the Republic of Tajikistan, as well as with the unified database of registered allegations and reports of crimes.

"Electronic registration of allegations and reports on crimes and incidents" is a socially significant project, since the effect of introducing the system will be noticeable not only to employees of the MIA of the Republic of Tajikistan, but, first of all, to ordinary citizens.

The realization of the project is primarily planned in the pilot region of Dushanbe. After acceptance and a trial operation of the "Electronic registration of allegations and messages on crimes and incidents" system, a thorough assessment and analysis of the results and progress in fulfilling the project objectives in the pilot region, including public awareness, as well as consideration of changes and/or confirmation of project activities comparable with respect to expected results at each stage of the implementation will continue in the regional centers and then in all regions of the Republic of Tajikistan. 
In the future, electronic registration of allegations and reports on crimes and incidents arriving at units of other law enforcement agencies (through the Customs Service, The Drug control Agency, Agency for state financial control and combating corruption, border troops, the State committee for national security and the Prosecutor General's Office) in the unified database should be provided. Moreover, the employees of these departments, within their powers and in accordance with the rules of work and interaction between departments, will be able to work with the unified database of allegations and reports of crimes and incidents.

In conditions of digitalization of all types of public services, among which a special place is taken by law enforcement activity, careful planning in the context of studying the issues of improving and optimizing all areas of criminal policy is required. In this connection, we must agree with the opinion that digitalization of criminal policy means the process and result of the introduction of quantitative methods for describing, assessing, analyzing and predicting criminality and response measures (including methods of mathematical statistics and mathematical modeling) into the practice of the formation and implementation of combating measures with criminality moved from the stage of futuristic planning to the stage of implementation (Maximov, Vasin, Valuskov \& Utarov, 2019).

Given that the use of new information technologies in law enforcement agencies will show high efficiency and prospects, it is necessary to continue work on the introduction of electronic registration in all criminal prosecution bodies. We hope that the project will demonstrate its uniqueness very soon, as the primary results will be more real than the usual reporting of statistical data and their generalized wording.

Peer-review: Externally peer-reviewed.

Conflict of Interest: The authors have no conflict of interest to declare.

Grant Support: The authors declared that this study has received no financial support.

Hakem Değerlendirmesi: Dış bağımsız.

Çıkar Çatışması: Yazarlar çıkar çatışması bildirmemiştir.

Finansal Destek: Yazarlar bu çalışma için finansal destek almadığını beyan etmiştir.

\section{References/Kaynakça}

Agency for statistics under the President of the Republic of Tajikistan. (2016). Tajikistan: 25 years of state independence. Statistical compilation. Dushanbe, Tajikistan: Author.

Agency for statistics under the President of the Republic of Tajikistan. (2019). Socio-economic situation of the Republic of Tajikistan (January-December of 2018). Retrieved from http://stat.ww.tj/posts/february2019/12180-2018-doklad.pdf. 
Agency for statistics under the President of the Republic of Tajikistan. (2020). Socio-economic situation of the Republic of Tajikistan (January-December of 2019). Retrieved from http://stat.ww.tj/files/12_\%202019\%20 доклад $\% 20$ русский $\% 20(1) \% 20(1)$.pdf.

Alekseev, A.I., Ovchinsky, V.S., \& Pobegailo, E.F. (2006). Russian criminal policy: overcoming the crisis. Moscow, Russia: Norma.

Alexandrov, A.S., \& Alexandrova, I.A. (2017). What manifesto of criminal policy we need, and what should not be manifested. Bulletin of the Nizhny Novgorod academy of the Ministry of Internal Affairs of Russia, №4 (40), 337-341.

Antonyan, Yu.M. (2015). Criminology: textbook for academic undergraduate. Moscow, Russia: Yurayt.

Bahridinzoda, S.E. (2016). On the introduction of criminological expertise in the Republic of Tajikistan: opinions and prospects. Actual issues of the reform of procedural legislation and law enforcement activity. Materials of the international scientific and theoretical conference. Dushanbe, Tajikistan.

Collection of legislation of the Russian Federation (2010), №8.

Collection of regulatory legal acts on police reform (2015). Dushanbe, Tajikistan: Polygraph Group.

Inshakov, S.M. (1997). Foreign criminology. Moscow, Russia: Infra-M-NORMA.

Esakov, G.A., Dolotov R.O., Filatova, M.A., Redchits, M.A., Stepanov, P.P., Tsai, K.A. (2017). Criminal policy: roadmap (2017-2025). Moscow, Russia.

Federal Law of Russian Federation “On the Prosecutor's Office of the Russian Federation”. (2011, February 7). Retrieved from http://docs.cntd.ru/document/902260214.

Gavrilov, B.Ya. (2008). Modern criminal policy of Russia: figures and facts. Moscow, Russia: Prospect.

Gilinsky, I.I. (2013). Deviantology: the sociology of criminality, narcotism, prostitution, suicide and other "deviations". Saint-Petersburg, Russia: Alef-Press.

Kogan, V.M. (1977). The social properties of criminality. Moscow, Russia: Academy of the Ministry of Internal Affairs of the USSR.

Kogan, V.M. (1983). Social mechanism of criminal-legal influence. Moscow, Russia: Nauka.

Kozhevnikov, I.N. (1998). Materials of the "round table". The problem of improving the criteria for evaluating the activities of internal affairs bodies in the field of criminality control. Moscow, Russia.

Kudryavtsev, V.N. (1971). The effectiveness of the criminal justice system. Socialist legality, №7. 13-18.

Luneev, V.V. (2005). Criminality of the XXI century: global, regional and russian trends. Moscow, Russia: Wolters Kluwer.

Luneev, V.V. (2013). Criminality against modernization. Russia and the modern world, №1 (78).

Luneev, V.V. (2016, October 10). Before proposing another reform, it is necessary to study the realities. The answer of the criminologist to the processist A.S. Alexandrov. Speech at the Round Table "Investigative Power: "for" and "against", IGP RAS / MASP. Moscow, Russia. Retrieved from http://www.iuaj.net/ node/ 2100 .

Luneev, V.V. (2017). The era of globalization and criminality. Moscow, Russia: Norma.

Malysheva, O.A. (2013). Ensuring the rule of law in pre-trial criminal proceedings. Moscow, Russia: Kolomna.

Malysheva, O.A. (2019). Pre-trial proceedings in the Russian criminal process: theory, practice, prospects. Moscow, Russia: Yurayt.

Maximov S.V. (1995). Brief criminological dictionary. Moscow, Russia: Lawyer.

Maximov, S.V., Vasin, Yu.G., Valuyskov, N.V., \& Utarov, K.A. (2019). Digitalization of criminal policy as a tool to overcome its asystemicity. All-Russian criminological journal, tome 13, №3, 395-407.

Nazarov, A.D. (2017). Investigative and judicial errors and the criminal procedural mechanism for their elimination: conceptual foundations (Doctoral dissertation). Saint-Petersburg State University, SaintPetersburg, Russia. 
Ostroumov, S.S., Panchenko, S.N. (1967). The new system of criminal statistics and its importance in the work of bodies engaged in the fight against criminality. Socialist legality, №1, 34-37.

Rahimzoda, R.H. (2014). Criminal-legal, criminological and operational-investigative characteristics of felonies and especially grievous crimes committed in the field of economy. Dushanbe, Tajikistan: Irfon.

Rogova, E.V., Yuldoshev, R.R. (2017). Criminal misconduct in the context of contemporary trends in criminal policy. Dushanbe, Russia: Er-Graf.

Saviuk, L.K. (2000). Legal statistics. Moscow, Russia: Yurist.

Shepeleva, O. (2019). Crimes and punishments: what to do with Russian prisons? Moscow, Russia.

Shklyaruk, M., Skugarevsky, D., Dmitrieva, A., Skifsky, I., \& Begtin I. (2015). Criminal statistics: mechanisms of formation, causes of distortion, ways of reforming. Research report. Saint-Petersburg - Moscow, Russia: Norma.

The list of priority areas for the development of science, engineering and technology in the Republic of Tajikistan for 2015-2020 (2014). Approved by the Decree of the Government of the Republic of Tajikistan dated December 4, 2014, №765. Unified state register of regulatory legal acts of the Republic of Tajikistan, №12, part 1.

The Federation Council proposed to create Unified center for criminal policy in Russia. (2017). Retrieved from https:/www.ugpr.ru/news/1563-v-rossii-mojet-poyavitsya-edinyy-tsent.

Titaev, K.D, Knorre, A., Kudryavtsev, V., \& Shklyaruk, M. (2017). Manifesto of the new criminology "Criminal policy based on data”. Retrieved from http://test.russia2035.ru/wpcontent/uploads/2017/06/new_criminology_ manifesto_fin.pdf.

Toropin, Yu.V. (2013). Latent crime and the use of its indicators in the activities of internal affairs bodies (Candidate dissertation). Moscow, Russia.

Vedernikova O.N. (2010). Materials of the "round table" held by the Academy of the Prosecutor General of the Russian Federation on May 28-29, 2010. Bulletin of the Academy of the Prosecutor General of the Russian Federation, №3, 65-71.

Volkov, V., Dmitrieva, A., Skugarevsky, D., \& Titaev, E. (2014). Criminal justice of Russia in 2009: comprehensive analysis of judicial statistics. Moscow, Russia: Statute.

Volkov, V.V., Paneyakh, E.L., \& Titaev, K.D. (2010). Reform of the Ministry of Internal Affairs of Russia: four problems and eight measures to solve them. Series "Analytical notes on the problems of law enforcement", $I P P E U S P b$. Saint-Petersburg, Russia.

Yuldoshev, R.R., Mahmadiev, Kh.Kh., \& Akbarzoda, A.A. (2018). Criminality in Tajikistan (1991-2016). Dushanbe, Tajikistan: Contrast.

Zabryansky, G.I. (2010). Methodology of the statistical study of criminality (introduction to criminological statistics). Moscow, Russia: Granitsa. 